\title{
Peran Sistem Informasi dalam Pengelolaan Supply Chain Management dan Aplikasinya di PD. Agro Selaparang Lombok Timur
}

\author{
Widia Febriana \\ widia@universitasbumigora.ac.id \\ Universitas Bumigora \\ Ika Nurul Qamari \\ ikanq@yahoo.com \\ Universitas Muhammadiyah Yogyakarta \\ Nuryakin \\ nuryakindr@gmail.com \\ Universitas Muhammadiyah Yogyakarta
}

\begin{abstract}
PD. Agro Selaparang Lombok Timur is a company engaged in supply chain management : drinking water during the period (AMDK), animal feed, iodized salt, and block ice products, as for the objectives of this study, among others: 1) Knowing the supply chain management structure in PD. Agro Selaparang, 2) Analyze information systems (information communication technology, expert support, electronic business processes), used in dealing with suppliers, 3) Identifying how exposure is information systems in supply chain management, problems that occur currently in PD. Agro Selaparang, East Lombok, is a government obstacle such as lack of sanitarian personnel, allocation of funds, inspection of ice block product samples, feed, iodized salt and drinking water in a low AGRO period (AMDK), a burden double work. There are no strict sanctions and a lack of cooperation between sectors, too affects the quality of products that do not meet the requirements, so it affects on the product management process, besides the lack of feed stock due to the company as a distributor. Based on the problems that occur, the role of the system is needed information with supply chain management. The purpose of information systems can be help supply chain management in the company. The research was carried out with a qualitative approach through direct observation, indepth interviews and documentation. The results showed that in the supply chain management process PD. Agro Selaparang East Lombok uses an integrated information system and one doors, through financial information systems.
\end{abstract}

Keywords : information systems, supply chain management

\section{Pendahuluan}

Perkembangan dan pertumbuhan ekonomi dunia, didorong karena adanya globalisasi yang berkembang secara signifikan dalam dunia pasar, hal ini mengakibatkan persaingan bisnis yang cukup ketat, sehingga mengakibatkan perusahaan memperluas atau memperbanyak layanan pasar dan membuat suatu produk yang bernilai jual yang tinggi terutama diperusahaan manufaktur. Dalam pembahasan ini, layanan yang dimaksud sebagai berikut : layanan supply chain, layanan pemasaran dan layanan manajemen operasi (Liu Weihua, Di Wang, 2019).

Fenomena bisnis yang seringkali muncul terkait rantai pasok sehingga, daya saing produk Indonesia menjadi rendah dan biaya logistik yang tinggi mengakibatkan proses pengiriman menjadi lambat. Hal ini dipengaruhi oleh fasilitas logistik yang masih konvensional, seperti pelabuhan dan 
konektivitas yang berkaitan antara pusat produksi dan konsumsi (Primiana, Azis, Juanim, Yunani, 2016). Sehingga diperlukan adanya penelitian mengenai Peran Sistem Informasi Dalam Pengelolaan Supply Chain Management dan Aplikasinya di PD. Agro Selaparang Lombok Timur. Salah satu yang mereduksi biaya logistik adalah dengan optimalisasi distribusi material dari pemasok, aliran material dalam proses produksi sampai dengan distribusi produk ke tangan konsumen (Widyarto, 2012). Hal ini Memberikan wawasan baru tentang peran kekuasaan dan kepercayaan yang memfasilitasi anggota rantai untuk mengumpulkan kemampuan mereka dalam menciptakan dan menghargai nilai bagi pelanggan dan diri mereka. Kekuatan dan kepercayaan menjadi salah satu faktor penting dalam kolaborasi manajemen rantai pasok, mengupas konsep kualitas manajemen rantai pasokan, dan memaparkan bahwa kualitas rantai pasokan dapat memberikan solusi pada tingkat pengelolaan rantaipasokan (Simatupang, T. M., dkk., 2013).

Peranan sistem informasi dalam administrasi bisnis dan proses supply chain management memberikan penghematan pada biaya input seperti waktu, tenaga kerja dan energi, dengan demikian memungkinkan realisasi keuntungan dan kepuasan pelanggan secara kolektif. Perusahaan manufaktur, membuat lebih aman dan lebih banyak lagi rantai pasokan yang efisien biaya berkat penggunaan sistem informasi yang efisien dalam penyediaan kedua perlengkapan dan bahan alat produksi dalam membuat kemasan air minum. Penerapan teknologi informasi menjadi lebih penting di dalam supply chain management (SCM) dalam hal proses pengemasan dan pemesanan (Kaya Ergun, 2012).

Perkembangan produksi dan pemasaran pada perusahaan yang bergerak di manufaktur pada PD. Agro Selaparang Lombok Timur dalam produksi pupuk peningkatannya mencapai 66,67\% di tahun 2020, sedangkan penjualan Es Balok pada tahun 2018 mencapai 50.151 Balok, pola pergeseran pada tahun 2019 mencapai 64.053 Balok. Perusahaan memasarkan 45.000 dus dalam sebulan air minum dalam kemasan (AMDK).

Dari hasil riset menyatakan bahwa pola pergeseran daerah urban yang masih menggunakan air minum khususnya air galon, untuk data isi ulang mencapai 13,8\%, jika dibandingkan dengan air minum dalam kemasan (AMDK) mengalami peningkatan penjualan hingga 6\%, pada tahun 2007 mencapai 7,2 \% pada tahun 2010. Sehingga masyarakat yang ada di kota lebih cendrung memilih mengkonsumsi air galon, isi ulang dan air minum dalam kemasan (AMDK) sebagai kebutuhan sehari-hari, bahkan penduduk kota suka memesan air galon isi ulang karena harganya jauh lebih murah 3 kali lipat dari harga air minum dalam kemasan (AMDK) (Raksanagara Ardini S, dkk., 2018).

\section{Tinjauan Pustaka}

Sistem informasi adalah subsistem yang bersangkutan dengan aset bisnis dan sumber daya yang disebabkan oleh aktivitas dan perubahan mendeteksi yang dapat diukur dengan uang, pemantauan, menilai dan transmisi hasil. Pada banyak isu-isu seperti produksi dan biaya operasi, harga, perencanaan laba, nilai pelanggan, harga, pembelian, penyewaan, kinerja keuangan dan penilaian, pemulihan investasi, dukungan untuk pengambilan keputusan disediakan dengan informasi yang diberikan dari sistem informasi. Bagian penting dari informasi ini merupakan dasar dari perencanaan rantai pasokan.

Informasi dari proses transaksi front-end dikirim ke kantor, untuk distribusi kepada para pemegang saham. Pada saat yang sama, sumber daya yang dibeli oleh back-end fungsi untuk distribusi ke anggota staf garis depan. Mayoritas fungsi back-office jatuh di bawah yurisdiksi dari departemen akuntansi dan keuangan. Proses supply chain management yang otomatis melalui teknologi sistem informasi, yang terdiri dari jaringan komputer yang digunakan untuk transaksi bisnis laporan dan peristiwa ekonomi yang terjadi dalam sebuah perusahaan manufaktur (Tesone, 2006). Misalnya, transaksi rantai pasokan terjadi sebagai bagian dari proses pengadaan yang digunakan untuk memperoleh sumber daya material untuk digunakan di perindustrian. 
Implementasi supply chain management yang sukses perlu dilakukan mengintegrasikan praktik proses mulai dari hulu, hilir dan internal. Disisi lain, untuk integrasi yang sukses ini, informasi memainkan peranan yang luar biasa penting. Kurangnya informasi atau informasi yang terdistorsi, berlalu dari satu ujung rantai pasokan ke yang lain, menyebabkan masalah yang signifikan, tetapi tidak terbatas pada investasi persediaan yang berlebihan, layanan pelanggan yang buruk, hilang pendapatan, rencana kapasitas yang salah arah, transportasi, yang tidak efektif dan produksi yang terlewat jadwal (Truong Quang Huy, dkk., 2016).

Supply chain management sebagai strategi manajemen dari seluruh fungsi bisnis yang meliputi beberapa aliran, hulu atau hilir, untuk beberapa aspek pada sistem rantai pasokan (Mentzer, 2001). Selanjtnya Mentzer manyatakan dalam supply chain management meliputi seluruh fungsi bisnis yang dikoordinasikan di dalam perusahaan dan perusahaan lain yang terdapat pada rantai pasokan, menambahkan bahwa supply chain management sebagai pengintegrasian aktivitas pengadaan bahan dan pelayanan, pengubahan menjadi barang setengah jadi dan produk akhir, serta pengiriman ke pelanggan. Seluruh aktivitas ini mencakup aktivitas pembelian dan outsourcing, ditambah fungsi lain yang penting bagi hubungan antara pemasok dan distributor (Heizer, 2011).

\section{Metode Penelitian}

Metode penelitian yang digunakan dalam penelitian ini adalah metode kualitatif dengan pendekatan studi deskriptif analitik, sebagaimana yang diungkapkan oleh Sugiyono (2019), tujuan penelitian kualitatif adalah untuk mendapatkan data yang mendalam, suatu data yang mengandung makna. Penelitian ini mengunakan penjelasan teori yang harus dibangun oleh peneliti berdasarkan data umum dalam observasi yang harus dianalisis, penjelasan dan interpretasi serta kesiapan, oleh karena itu peneliti memerlukan sebuah pendekatan tersendiri dalam penelitian ini, yang arah dan tujuannya kepada pemahaman terhadap suatu masalah berdasarkan prespektif yang sesuai dengan arah dan tujuan tersebut adalah pendekatan penelitian deskriptif kualitatif, di mana dengan mengetahui peran sistem informasi dalam pengelolaan supply chain management di PD. Agro Selaparang Lombok Timur. Metode kualitatif secara signifikan dapat mempengaruhi substansai penelitian, artinya bahwa metode kualitatif menyajikan secara langsung hakikat hubungan antar peneliti dan informan, objek dan subjek penelitian.

Analisis data menurut Bogdan and Biklen adalah upaya yang dilakukan dengan jalan bekerja dengan data, mengorganisasikan data, memilah-milahnya menjadi satuan yang dapat dikelola, mensintesiskannya, mencari dan menemukan pola, menemukan apa yang penting dan apa yang dipelajari, dan memutuskan apa yang dapat diceriterakan kepada orang lain (Meleong, 2012).

Proses analisis data dimulai dengan menelaah seluruh data yang tersedia dari berbagai sumber, yaitu dari wawancara, pengamatan yang sudah dituliskan dalam catatan lapangan, dokumen pribadi, dokumen resmi, gambar, foto, dan sebagainya.

\section{Hasil dan Pembahasan}

\section{1. $\quad$ Struktur Supply Chain Management PD. Agro Selaparang Lombok Timur}

Informasi yang peneliti peroleh, perusahaan yang ada di PD. Agro Selaparang Lombok Timur dibagi menjadi 5 bagian, 3 diantaranya di bawah kewenangan Direktur Operasional, yang pertama adalah bagian produksi dan manufaktur, di mana bagian ini itu membawahi 3 unit usaha yaitu : 1) Pabrik Es Balok, 2) Pakan, dan 3) Garam Beryodium. Bagian yang kedua yaitu agribisnis, yang memproduksi pupuk dan obat-obatan. Bagian ke yang ketiga adalah pendistribusian dan perdagangan (Perindup) yang menangani masalah air minum dalam kemasan Agro (AMDK). Berikut akan dideskripsikan struktur supply chain management atas produk-produk PD. Agro Selaparang Lombok Timur 
1) Struktur Supply Chain Management Pabrik Es Balok

Pihak-pihak yang terlibat dalam model supply chain management Es Balok di PD. Agro Selaparang Lombok Timur adalah sumber daya manusia yang terdiri dari staf yang ada di perusahaan, nelayan dan pemilik-pemilik kapal yang ada di pulau Lombok. Pengecer yang terdiri dari pedagang kecil dan pengecer pabrik, yang membeli Es Balok dari perusahaan dan menjual kembali secara ecer, konsumen yaitu: pembeli akhir yang membeli Es Balok dari perusahaan ataupun melalui pengecer.

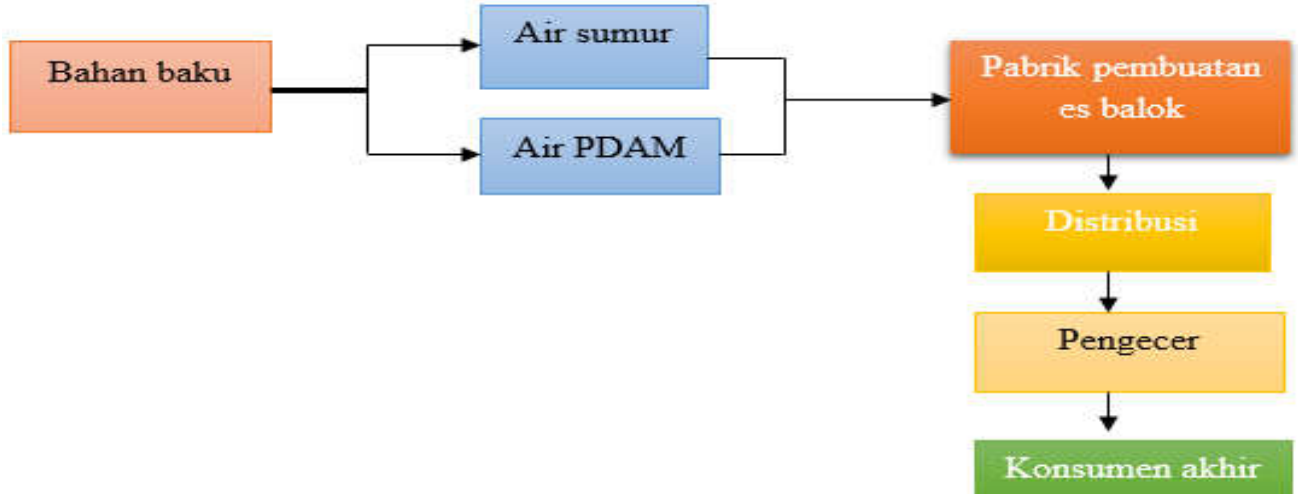

\section{Gambar 1. Proses Supply Chain Management EsBalok PD. Agro Selaparang Lombok Timur}

\section{2) Struktur Supply Chain Management Pakan PD. Agro Selaparang Lombok Timur}

Proses rantai pasokan ini melibatkan semua interaksi antara produsen, distributor dan pelanggan. Rantainya meliputi waktu, biaya, dan transfortasi transfer uang tunai dan uang kredit dan bahan baku, secara umum penerapan konsep manajemen rantai pasokan akan memberikan manfaat bagi peningkatan pendapatan, penurunannya biaya, pemanfaatan aset yang semakin tinggi, peningkatan laba dan usaha yang semakin besar.

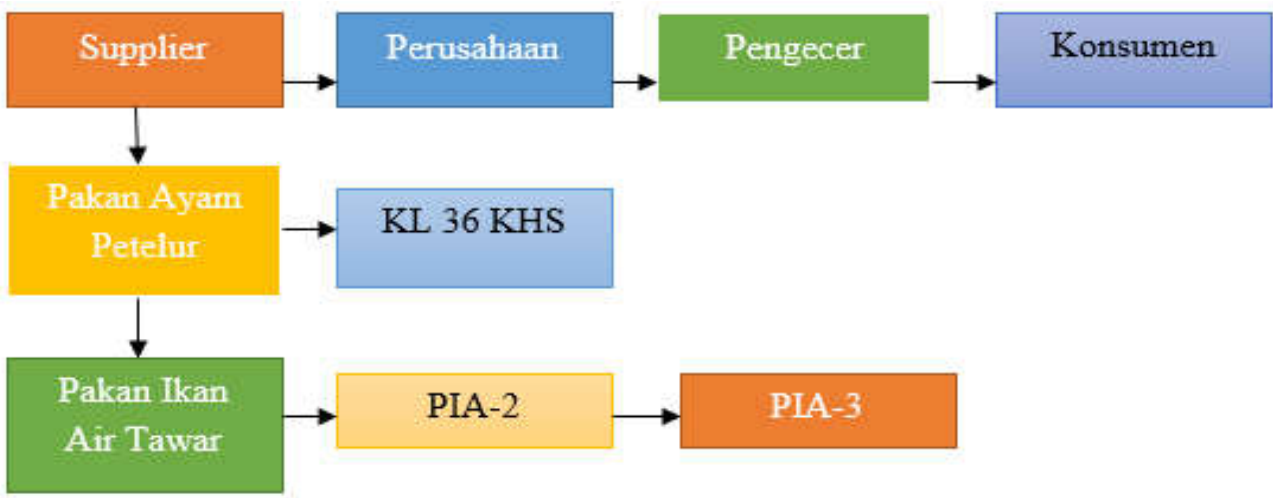

Gambar 2. Supply Chain Management Pakan PD. Agro Selaparang Lombok Timur 
3) Struktur Supply Chain Management Garam Beryodium di PD. Agro Selaparang Lombok Timur

Proses supply chain management produk garam beryodium pada PD. Agro Selaparang Lombok Timur yaitu kinerja manajemen integrasi aktivitas produksi pengadaan bahan dan pelayanan, pengubahan setengah jadi dan produk akhir, serta pengiriman kepelanggan. Seluruh aktivitas ini mencakup aktivitas pembelian dengan tujuan pembangunan rantai pemasok yang memusatkan perhatian untuk memaksimalkan nilai bagi pelanggan, persaingan bukan lagi antar pengusaha antar supply chain. Tapi yang diutamakan adalah untuk dapat mempertahankan, kualitas dan ketepatan waktu pengiriman merupakan hal yang penting karena menyangkut kepercayaan dari konsumen dan apabila produk dikirim tidak tepat waktu maka akan mengalami kerugian dan kepercyaan konsumen, berikut adalah alur supply chain management garam beryodium PD. Agro Selaparang Lombok Timur.

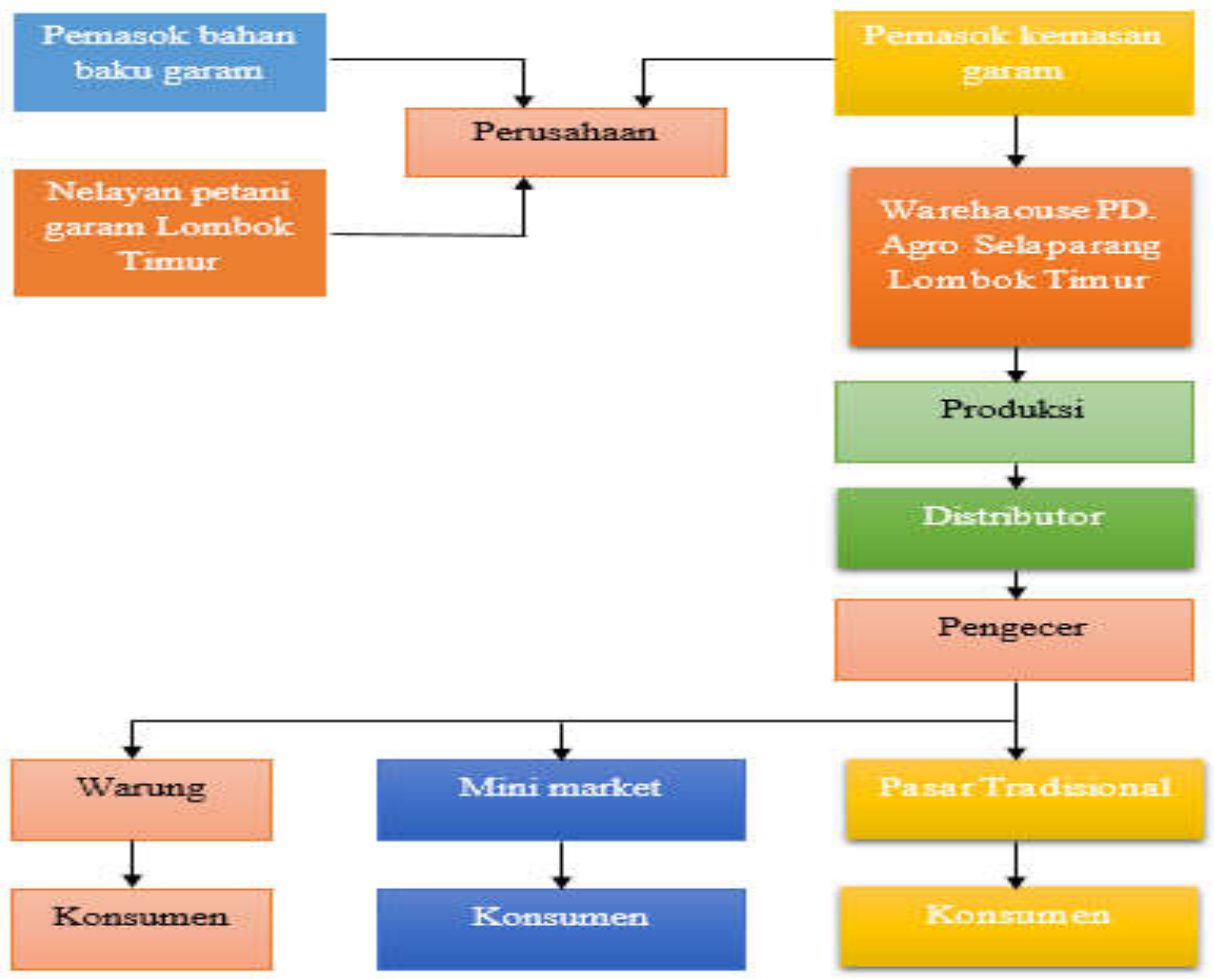

Gambar 3. Supply Chain Management Garam Beryodium PD. Agro Selaparang Lombok Timur 
4) Sistem Informasi supply chain management air minum dalam kemasan Agro (AMDK) di PD. Agro Selaparang Lombok Timur

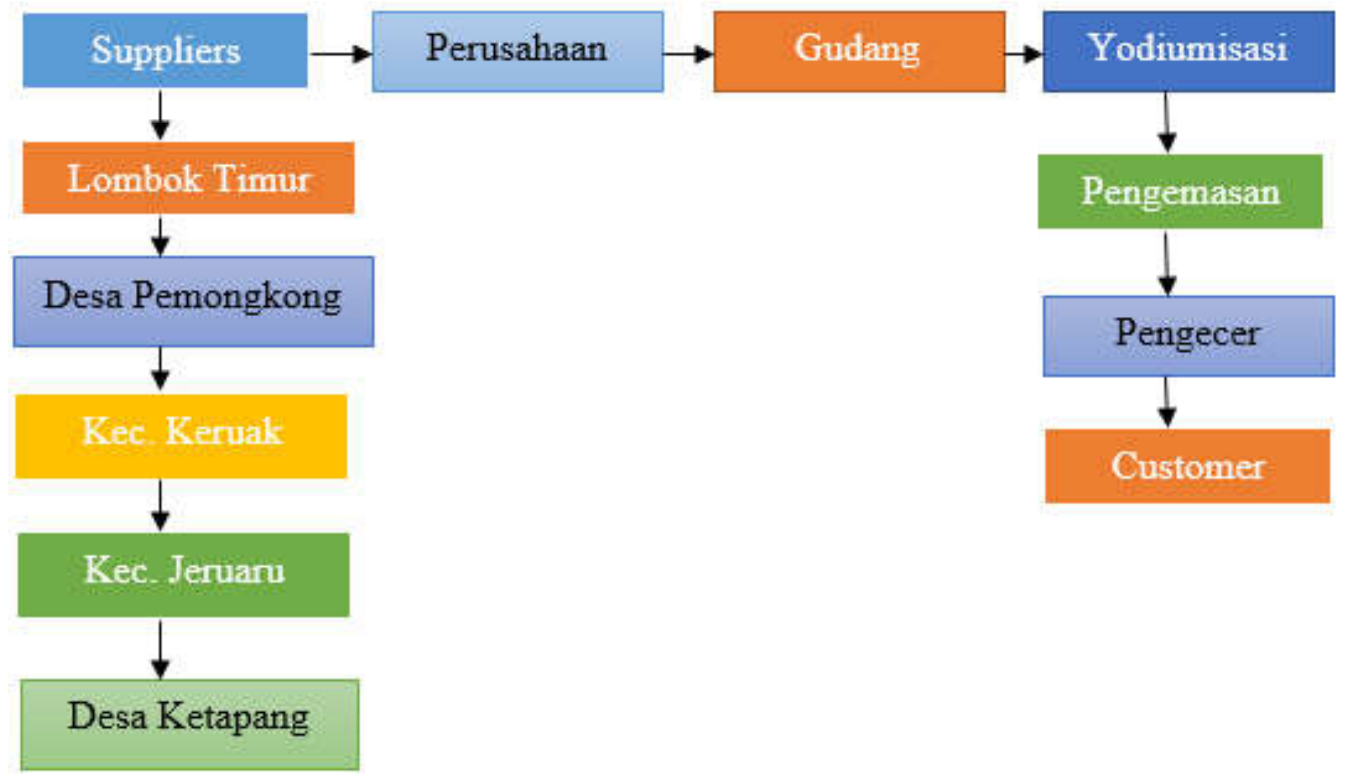

\section{Gambar 5. Supply Chian Management Air Minum Dalam Kemasan di} PD. Agro Selaparang Lombok Timur

4.2. Sistem Informasi Dalam Supply Chain Management Yang Digunakan Dalam Berurusan Dengan Pemasok di PD. Agro Selaparang Lombok Timur

1) Sistem Informasi Supply Chain Management Es Balok PD. Agro Selaparang Lombok Timur

Penerapan sistem informasi supply chain management PD. Agro Selaparang Lombok Timur memberikan kemampuan akses secara langsung pada semua konsumen dan rekan bisnis kedalam sistem sesuai dengan fungsinya dan kebutuhan masing-masing seperti pemasanan, dukungan teknis, pemeriksaan status pembelian atau pengiriman, dokumen-dokumen bisnis, status pembayaran, utang-piutang dan sebagainya. Sistem informasi sebuah sebuah sistem yang menghubungkan rantai supply chain management antara perusahaan, pemasok dan supplier.

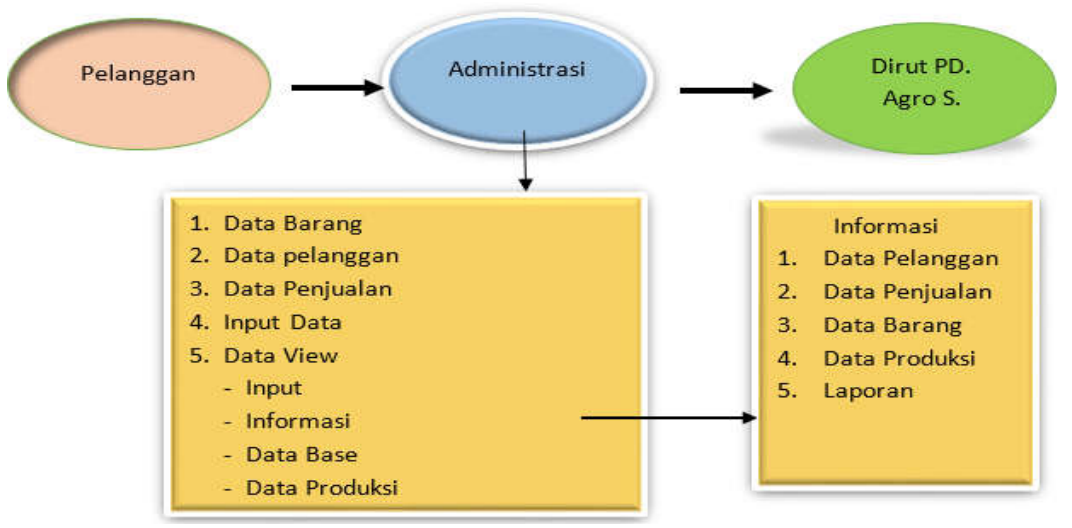

Gambar 6. Sistem Informasi Es Balok PD. Agro Selaparang Lombok Timur 
Berikut ini sistem informasi HIPO yang diadopsi oleh PD. Agro Selaparang

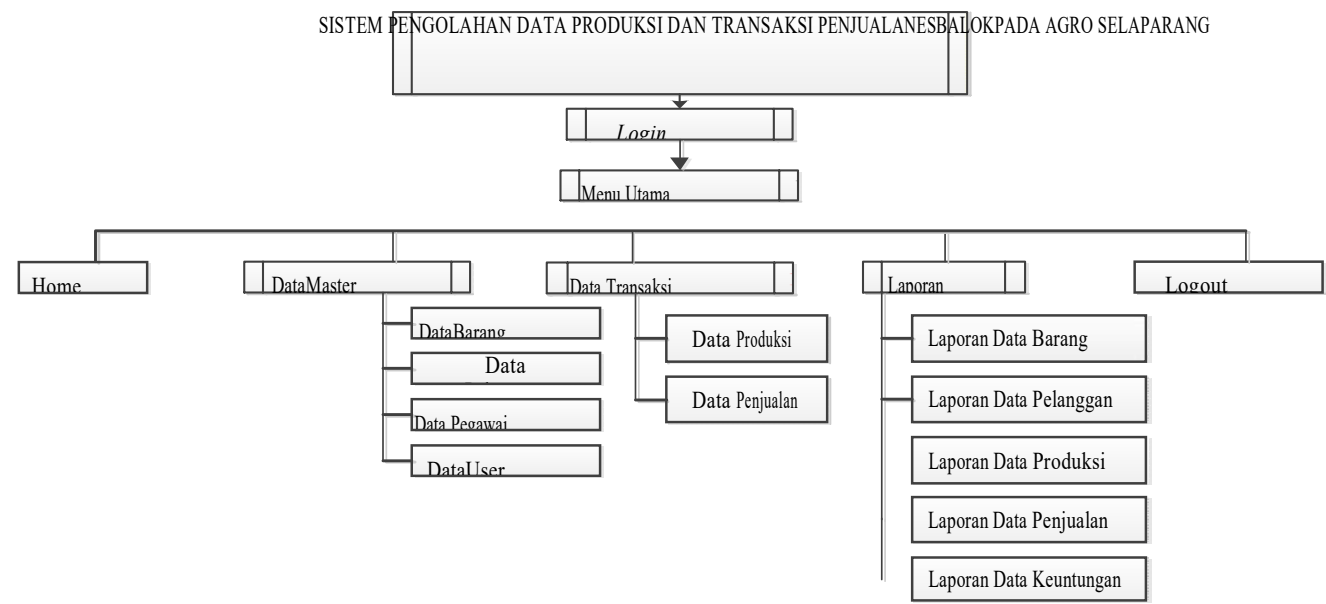

Gambar 7. Sistem Informasi PD. Agro Selaparang Lombok Timur

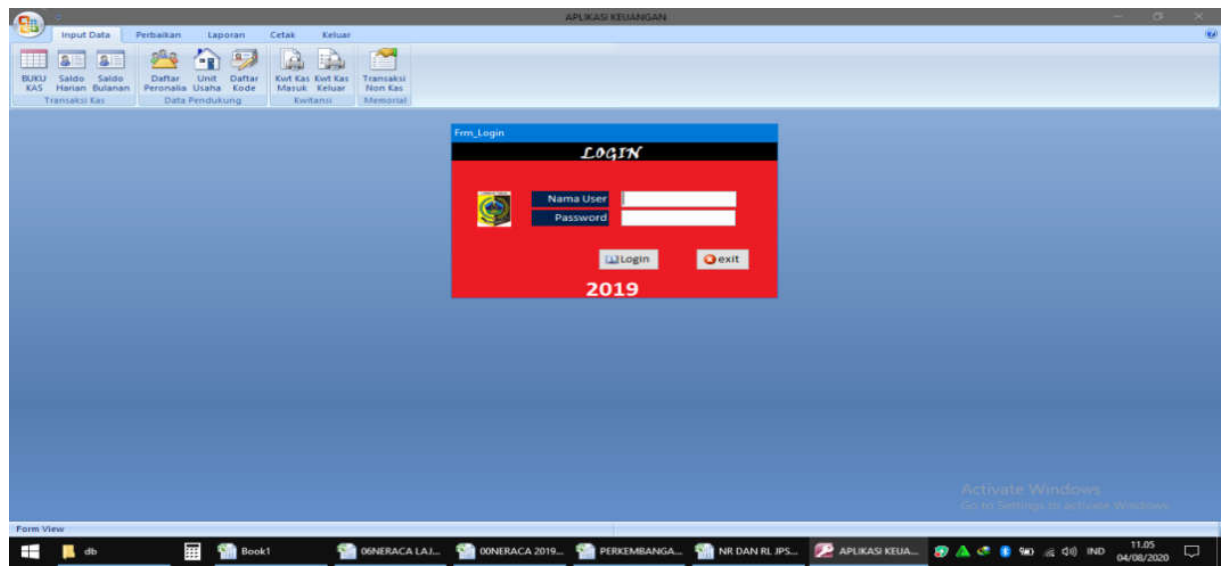

Gambar 8. Form Login sistem informasi PD. Agro Selaparang Lombok Timur

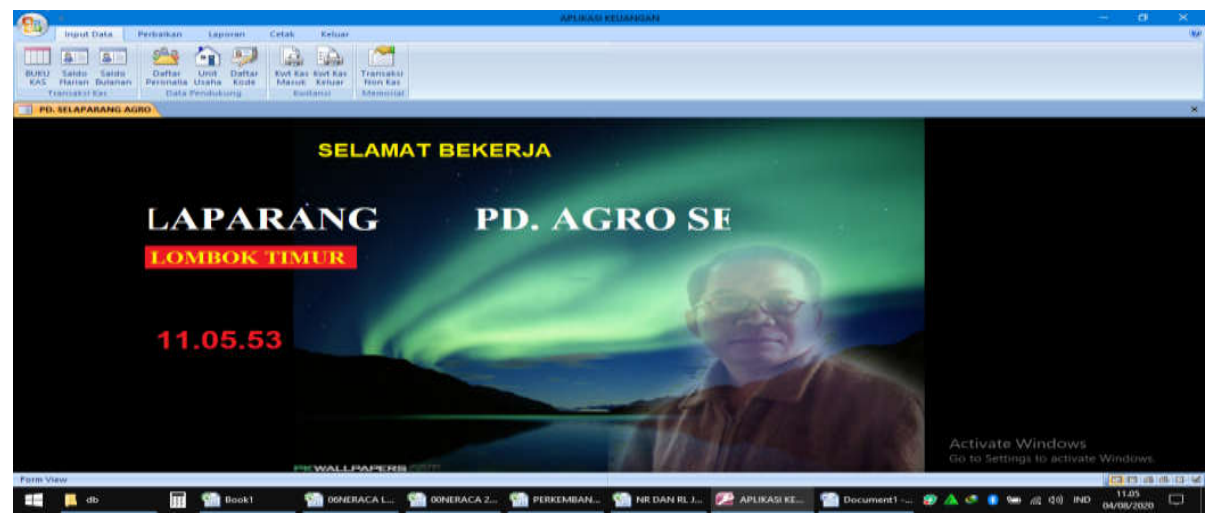

Gambar 9. Gambar Masuk Admin Sistem Informasi PD. Agro Selaparang Lombok Timur 


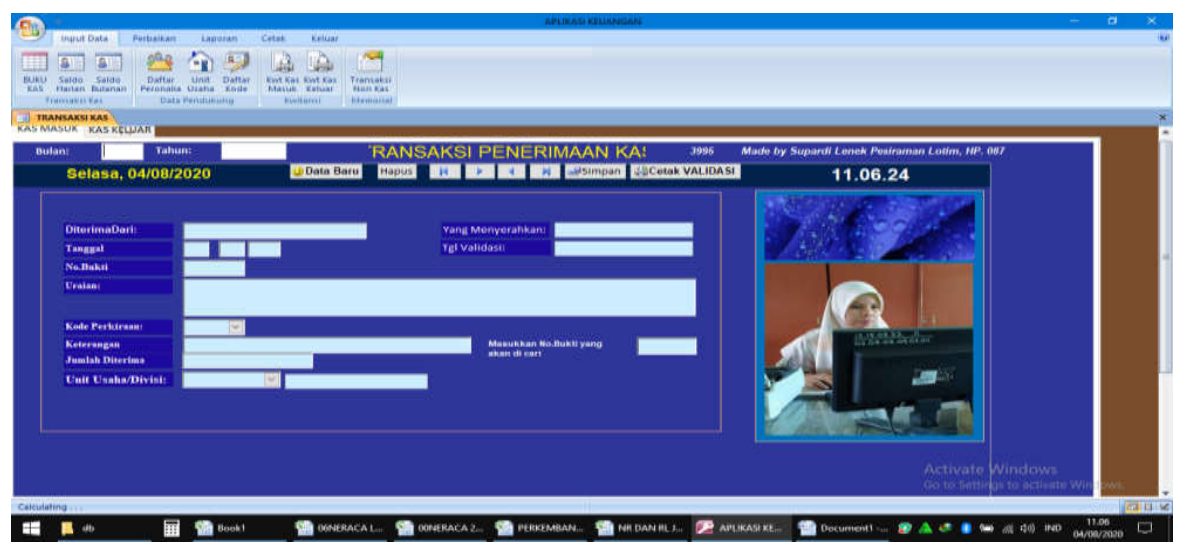

Gambar 10. Form Transaksi Penerimaan Kas Sistem Informasi PD. Agro Selaparang Lombok Timur

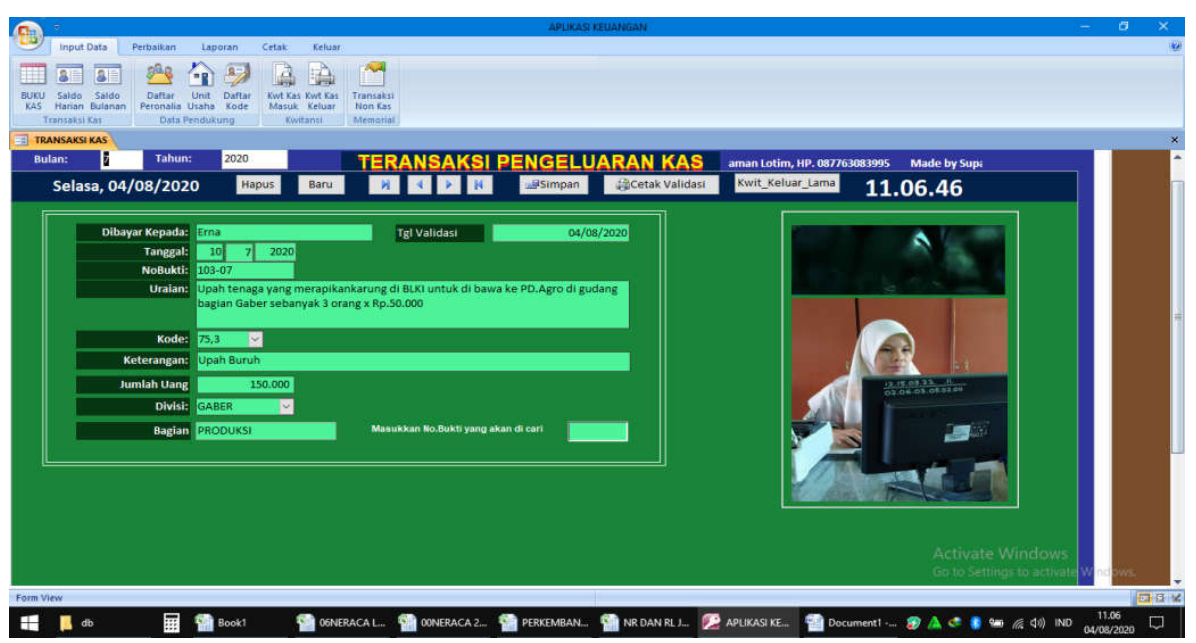

Gambar 11. Form transaksi penjualan kas sistem informasi PD. Agro Selaparang Lombok Timur

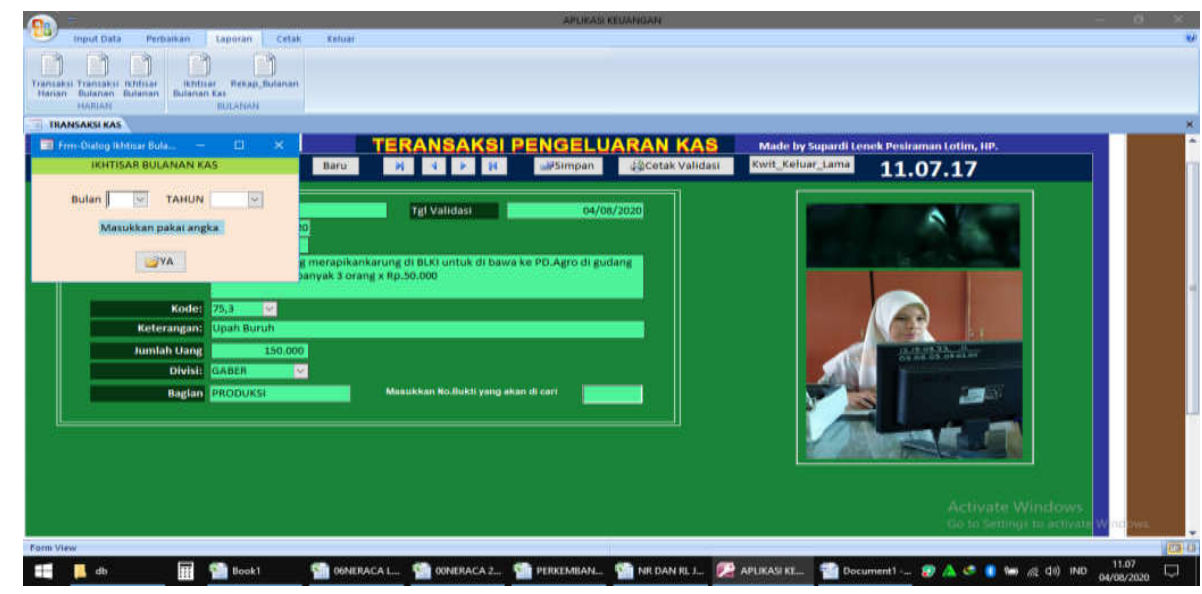

Gambar 12. Form Login ke Sistem yang berikutnya di PD. Agro Selaparang Lombok Timur 
2) Sistem Informasi Supply Chain Management Pakan PD. Agro Selaparang Lombok Timur

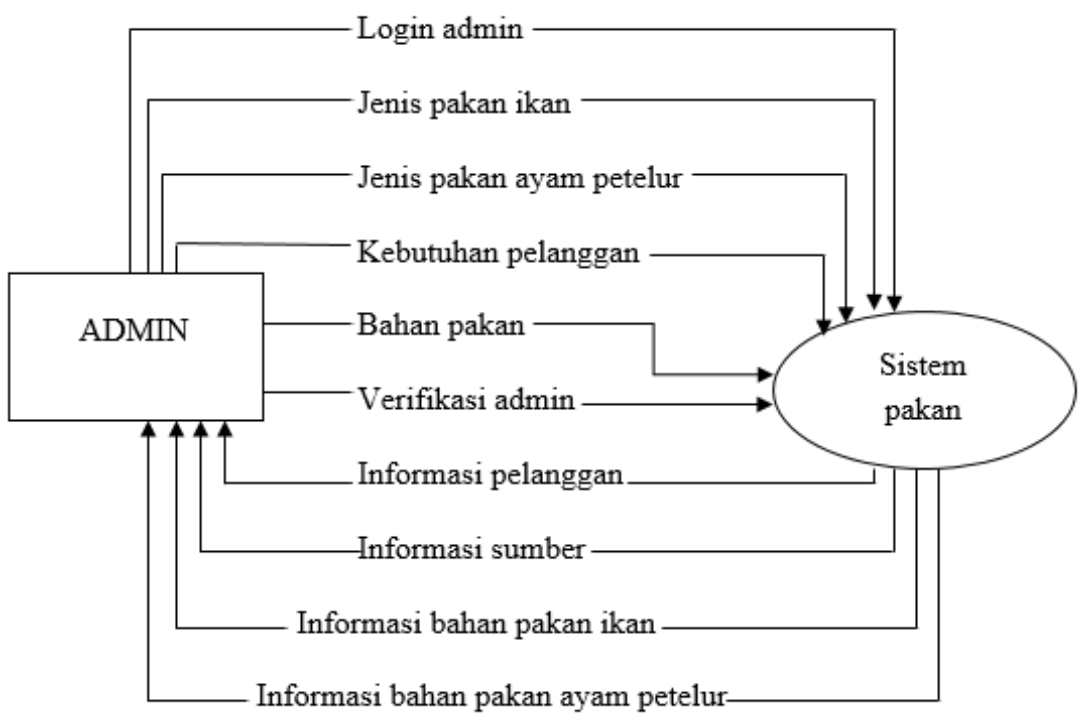

\section{Gambar 13. Sistem Informasi Pakan PD. Agro Selaparang Lombok Timur}

Gambar di atas merupakan diagram yang terdiri dari suatu proses sistem informasi yang ada di perusahaan, di dalam sistem informasi pakan (ikan dan ayam petelur), terdapat masukan atau laporan dari admin, prosesnya mulai dari login admin, jenis pakan ikan, jenis pakan ayam petelur, kebutuhan pelanggan, bahan pakan, verifikasi admin, informasi pelanggan, informasi sumber, informasi pakan ikan dan informasi bahan pakan ayam petelur. Berikut ini sistem informasi Entity Relationship Diagram (ERD) yang diadopsi oleh PD. Agro Selaparang Lombok Timur.

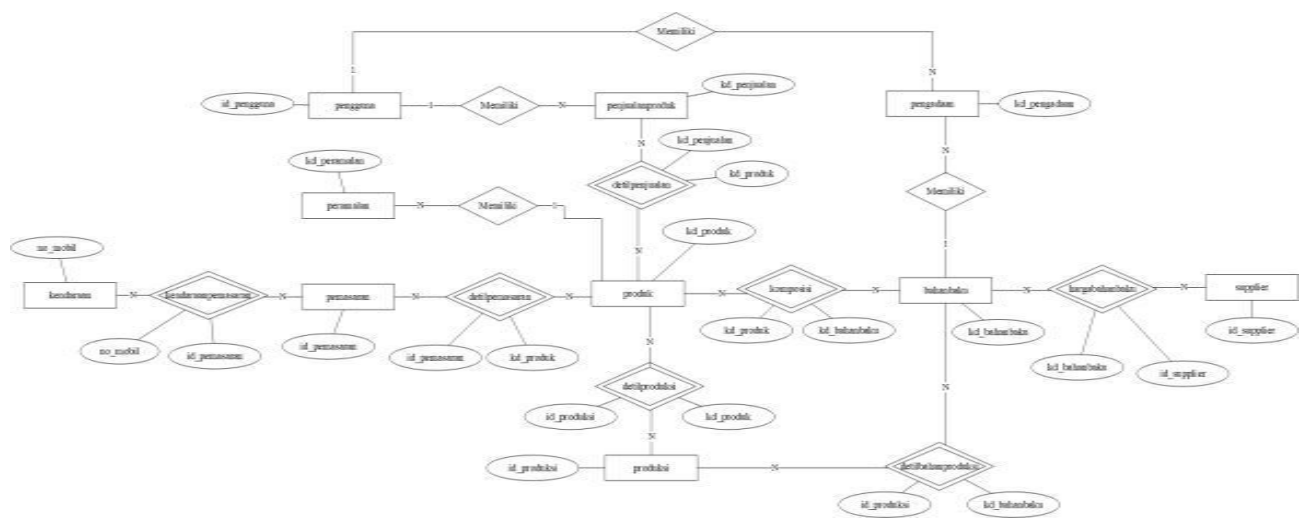

Gambar 14. Entity Relationship Diagram (ERD) Sistem Informasi Supply Chain Management PD. Agro Selaparang Lombok Timur. 
Gambar di atas menggambarkan analisis basis data yang merupakan suatu tahapan yang digunakan untuk menggambarkan data dalam bentuk hubungan antara sub-sub bagian yang terlibat dalam sistem informasi yang akan dibangun, PD. Agro Selaparang Lombok Timur menggunakan analisis basis data entity relationship diagram (ERD).

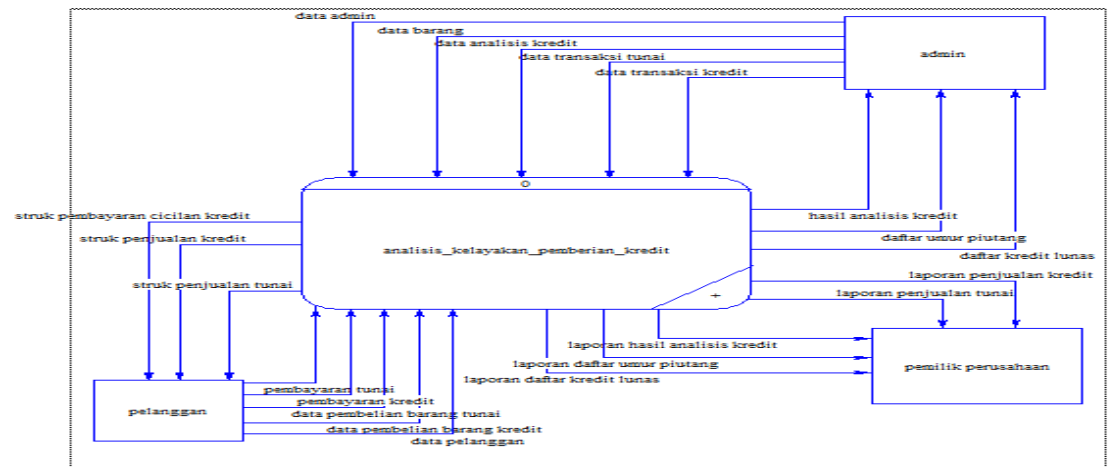

\section{Gambar 15. Aliran Sistem Informasi Suplly Chain Management PD. Agro Selaparang Lombok Timur.}

Diagram ini suatu pemodelan untuk menggambarkan dari setiap fungsional untuk menjelaskan secara global, data ini digunakan untuk proses atau menggambarkan aliran data kedalam dan keluar sistem.

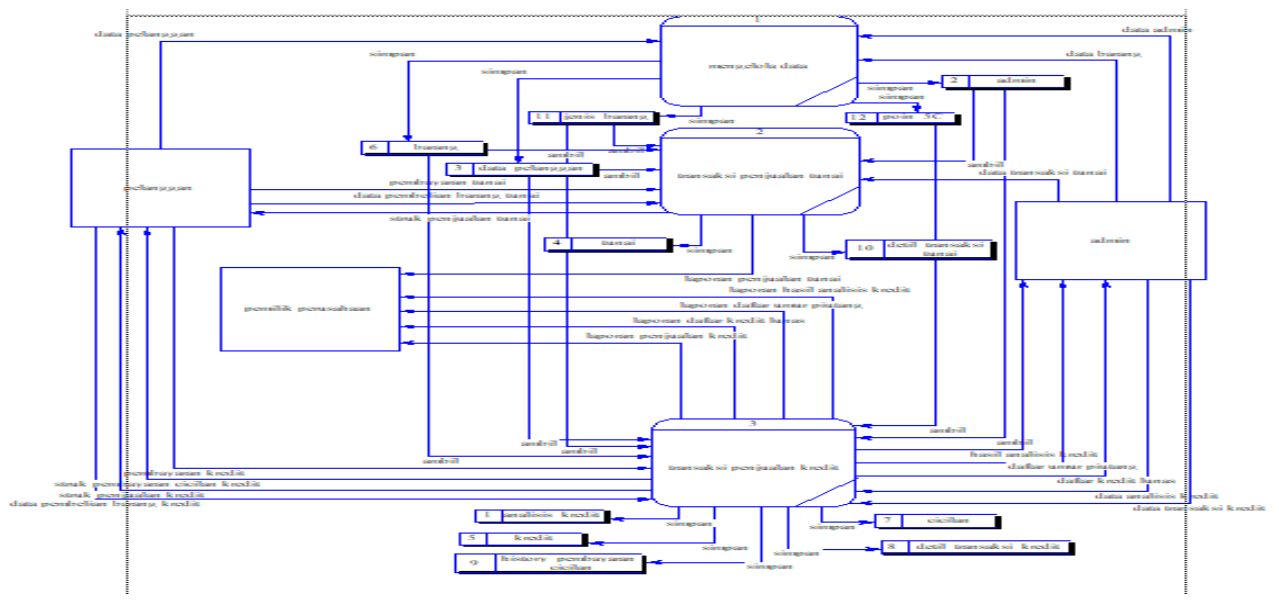

\section{Gambar 16. DFD Sistem Informasi Supply Chain Management di PD. Agro Selaparang Lombok Timur}

Data diagram flow menggambarkan aliran data yang ada dan menguraikan proses-proses yang terjadi ke dalam sistem sampai pada tahap proses yang leboh detail, pada diagram data flow diagram PD. Agro Selaparang Lombok Timur. 


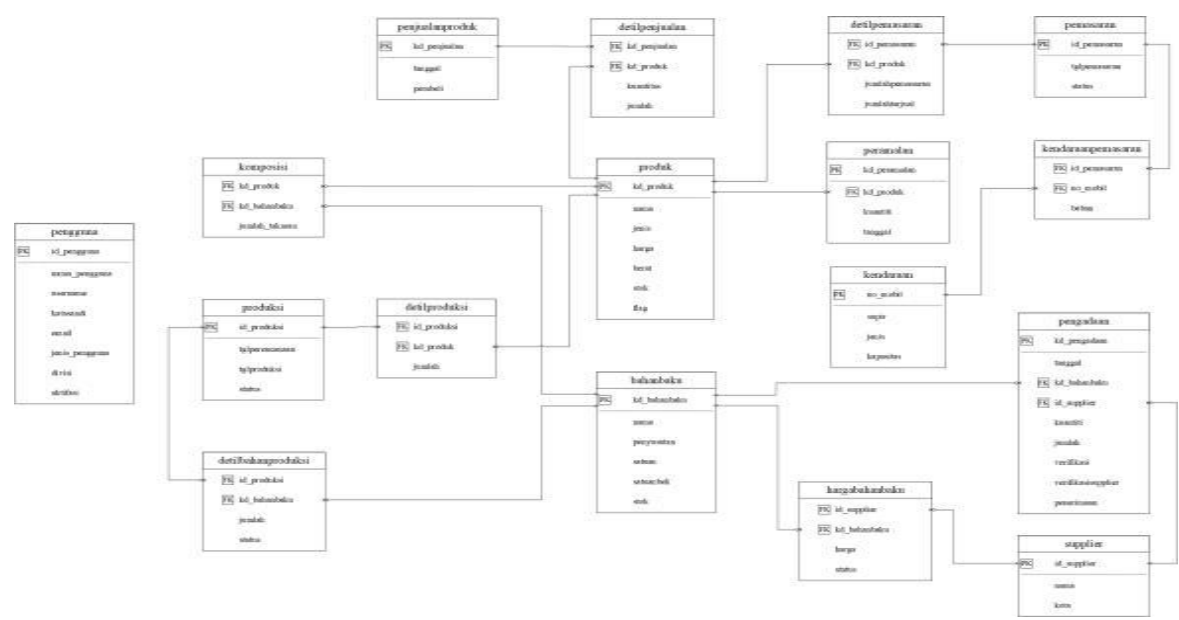

Gambar 17. Relasi Sistem Informasi Supply Chain Management di PD. Agro Selaparang Lombok Timur.

3) Sistem Informasi Supply Chain Management Garam Beryodium diPD. Agro Selaparang Lombok Timur

Sistem informasi yaitu komponen yang saling berhubungan dan bekerjasama untuk mengumpulkan, memproses, menyimpan, dan mendistribusikan informasi yang salaing terkait dengan penggunaan untuk mendukung pengambilan keputusan, koordinasi dan proses control yang terkandung di dalamnya.

PD. Agro Selaparang Lombok Timur mengggunakan sistem organisasai untuk proses pengiriman produk garam beryodium dan layanan kepada pelanggan, dalam rantai ini, jaringan yang berasal dari berbagai organisasi yang berbeda terhubung satu sama lain dan memiliki tujuan yang sama, yaitu untuk melakukan akuisisi barang yang baik, dan proses pertukaran barang juga merupakan bagian dari supply chain management.

4) Sistem Informasi supply chain management air minum dalam kemasan Agro (AMDK) di PD. Agro Selaparang Lombok Timur

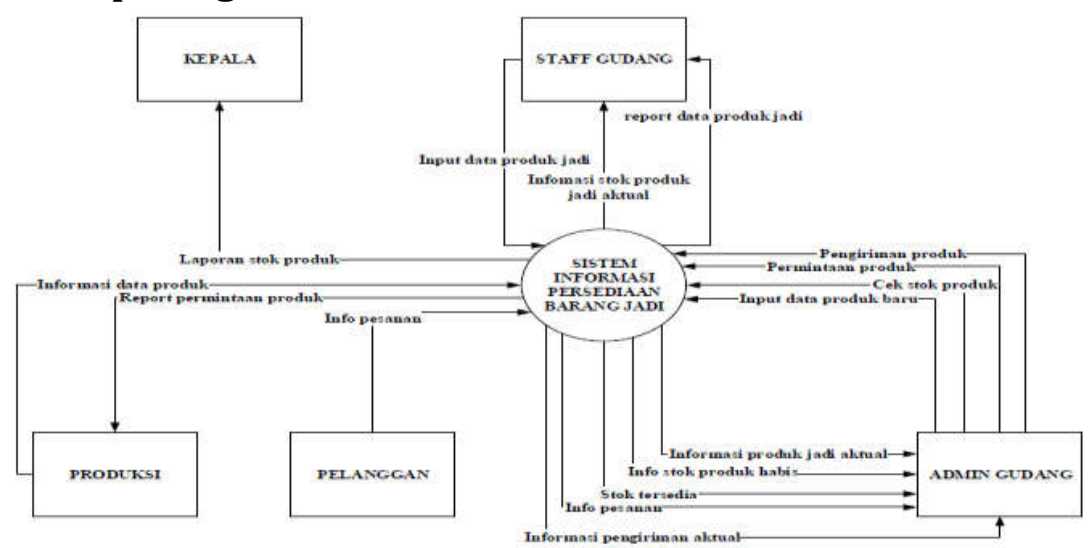

Gambar 18. Proses Supply Chain Management Air Minum Dalam Kemasan Agro (AMDK). 
Implementasi sistem informasi adalah cara yang dilakukan agar sistem tersebut dapat di akses oleh beberapa pihak terkait juga untuk website dapat di akses oleh masyarakat umum yang memperlukan informasi terkait PD. Agro Selaparang Lombok Timur sistem informasi ini di upload pada sebuah hosting yang kemudian dapat diakses melalui smartphone setelah dilakukan implementasi, diharapkan masyarakat umum dapat lebih jauh tentang produkproduk PD. Agro Selaparang Lombok Timur.

\subsection{Peran Sistem Informasi dalam Pengelolaan Supply Chain Management pada PD. Agro Selaparng Lombok Timur}

Peran strategis sistem informasi manufaktur antara lain meminimalkan potensi negatif perusahaan, menyeimbangkan dengan kompetitor, mendukung strategi bisnis dan mendukung nilai kompetitif berbasis manufaktur. Beberapa alasan penggunaan teknologi informasi dalam supply chain management adalah: pemasaran, ekonomis, organisasional, teknologi supply chain management (SCM) semakin banyak digunakan oleh perusahaan sebagai upaya dalam meningkatkan daya saing.

Perkembangan teknologi yang cepat menimbulkan peluang yang besar bagi dunia usaha untuk berpartisipasi dalam bisnis global, akan tetapi persaingan menjadi lebih ketat. Salah satu cara untuk bisa miningkatkan nilai kompetitif perusahaan adalah dengan melakukan efisiensi dalam rantai pasokan. Persoalan dalam tesis ini adalah bagaimana peran teknologi informasi dalam mendukung supply chain management (SCM). Peran strategis sistem informasi manufaktur antara lain meminimalkan potensi negatif perusahaan, menyeimbangkan dengan kompetitor, mendukung strategi bisnis dan mendukung nilai kompetitif berbasis manufaktur. Beberapa alasan penggunaan teknologi informasi dalam supply chain management (SCM) adalah: pemasaran, ekonomis, organis Perusahaan sekarang berfokus pada perencanaan strategis dengan tujuan untuk perencanan jangka panjang dan merubah organisasi untuk meningkatkan nilai kompetitif.

\section{KESIMPULAN}

1) Proses supply chain management Es Balok PD. Agro Selaparang Lombok Timur untuk mengetahui aliran supply chain es balok dimulai dari bahan baku sampai ke konsumen akhir, perusahaan tidak berhubungan langsung dengan konsumen terakhir dalam menyalurkan produknya, melainkan melalui pengecer yang merupakan konsumen langsung bagi perusahaan. Proses supply chain management Pakan PD. Agro Selaparang Lombok Timur yaitu Supplier, perusahaan, pengecer dan custumer. Proses supply chain management garam beryodium di PD. Agro Selaparang Lombok Timur yaitu pemasok bahan baku garam, pemasok bahan baku garam dari nelayan petani garam Lombok Timur, perusahaan, pemasok kemasan garam, warehaouse PD. Agro Selaparang Lombok Timur, produksi, distributor, pengecer, konsumen akhir. Supply Chain Air Minum Dalam Kemasan (AMDK) PD. Agro Selaparang Lombok Timur supplier, perusahaan, pengecer dan customer.

2) Berdasarkan hasil wawancara, sistem informasi yang digunakan oleh PD. Agro Selaparang Lombok Timur adalah sistem informasi Hippo, Entity Relationship Diagram (ERD) dan Data Diagram Flow

3) Peran strategis sistem informasi manufaktur antara lain meminimalkan potensi negatif perusahaan, menyeimbangkan dengan kompetitor, mendukung strategi bisnis dan mendukung nilai kompetitif berbasis manufaktur. Beberapa alasan penggunaan teknologi informasi dalam supply chain management adalah: pemasaran, ekonomis, organisasional, teknologi supply chain management (SCM) semakin banyak digunakan oleh perusahaan sebagai upaya dalam meningkatkan daya saing. 


\section{Daftar Pustaka}

Heizer, J. dan B. R. (2011). Priciples of Operations Management. United States of America. Pearson: 698.

Kaya Ergun, M. A. (2012). Role of information systems in supply chain management and its application on five-star hotels in Istanbul. Vol. 3(No. 2), 138-146.

Liu Weihua, Di Wang, S. L. and X. S. (2019). Service supply chain management: a behavioural operations perspective. Modern Supply Chain Research and Applications, Vol. 1(No. 1), 26313871.

Meleong, L. J. (2012). Metodologi Penelitian Kualitatif. Bandung: RemajaRosda Karya.

Mentzer, E. A. (2001). Defining Supply Cahin Management. Journal of Business Logistics. Vol. 20(No. 2), 1-25.

Primiana, Azis, Juanim, Yunani, \& H. (2016). Improvement Strategy for Supply Chain Performance of Garment Industry to Decrease Logistics Cost and Enhace Competitiveness. Journal of Industrial and Intelligent Information. Vol. 4(No. 2), 121-124.

Raksanagara Ardini S, Sukhriyatun Fitriyah, Irvan Afriandi, Hadyana Sukandar, S. Y. I. S. (2018). Aspek Internal dan Eksternal Kualitas Produksi Depot Air Minum Isi Ulang: Studi Kualitatif di Kota Bandung. Vol. 50(No. 1).

Simatupang, T. M., Handayati, Y., \& Perdana, T. (2013). A New Collaborative Approach for Horticultural Supply Chain. In T. M. Simatupang, Logistic and Supply Chain in Indonesia: Emerging Practices. Bandung: Bandung: SBM ITB.

Sugiyono. (2019). Metode Penelitian Kuantitatif, Kualitatif dan R \& D. Bandung: Alfabeta.

Tesone, D. . (2006). Hospitality Information Systems and E-commerce. Wiley, Hoboken, NJ.

Truong Quang Huy, Paulo Sampaio, Maria Sameiro Carvalho, Ana Cristina Fernandes, D. T. B. A. and E. V. (2016). An extensive structural model of supply chain quality management and firm performance. Vol. 33(No. 4), 444-464.

Widyarto, A. (2012). Peran Supply Chain Management dalam Sistem Produksi dan Operasi Perusahaan. Benefit Jurnal Manajemen dan Bisnis,. Vol. 17(No.2), 91-98. 
TARGET : JURNAL MANAJEMEN DAN BISNIS | e-ISSN : 2715-9361 | Vol. 3 No. 2 | Desember 2021 DOI https://doi.org/10.30812/target.v3i2.1633 